\title{
POST-RENOVATION EVALUATION OF THE STREET DISTRICT AND THE SHOPHOUSES ALONG MINQUAN STREET, SANXIA TOWNSHIP, TAIPEI CITY
}

\author{
A case study of evaluations by residents and businesses \\ 台北県三峡鎮民権街町屋区の再整備の使用評価について \\ 住民と商家の評価を例として
}

\section{Yu-Peng LAI* and Chih-Kao NIEH**}

賴 裕 鵬, 聶 志 高

\begin{abstract}
The main objective of this study is to investigate the post-renovation conditions of residences and evaluate the street district and the shophouses along Minquan Street of Sanxia Township, Taipei City. We conducted a field investigation and a questionnaire survey targeting shophouses along this street. Post-questionnaire data revealed that users felt that shophouse renovations were contributive to the renewed business development. In addition, improvements in exterior environmental appearances mostly led to positive appraisals by shophouse users. However, the actual demands for pubic facilities of local users remained unsatisfactory. Regarding interior renovations of shophouse, the occupying land area of shophouse seemed to meet the basic demands for businesses. Additionally, installation of air conditioning system is required.
\end{abstract}

Keywords: Minqua Street of Sanxia Township, shophouse district renovation, post-occupancy evaluation 三峡鎮民権街，町屋区の再整備，使用評価

\section{Research Motivations and Objectives}

During the Japanese colonial period, abundant shophouses with "Five-Foot Waysi" were constructed within cities and townships under the implementation of urban planning, and the above architectural forms are still widespread throughout the entire island of Taiwan. Currently, most of the shophouse clusters are leaning towards the tendency of preservation and renovation; nevertheless, in reality, controversies lie in property rights issues and the passive attitude of residents towards limiting the renovation operations to merely frontal wall repairs; in contrast, the improvement of interior spaces, and the renewal and restoration of living function are rarely considered. The reason for the above lies within the following 5 key points:

(1) Legal Issues: Since the announcement and implementation of the Cultural Heritage Preservation Act (CHPA) in 1982, many traditional shophouses have been declared historic buildings and are protected under the CHPA, with renovation and preservation rules stipulated within the act. However, if CHPA Article 36 designates the traditional shophouse clusters as historical districts for preservation, the shophouses will be required to be preserved by what can only be described as a forced-freezing method, designed to halt all further developments to keep original appearances and interiors intact. Any arbitrary alteration or modification of a shophouse is now strongly prohibited. However, under private property rights, owners of shophouses can and have expressed their strong condemnation of these restrictions. Therefore, recent cases of shophouse preservation in Taiwan will still be following the "Urban Planning Law" that designates groups of shophouses either as a "historic preservation district" or as a "special purpose district." Together with land acquisition, subsidies for renewal and development, and transfer of development rights (TDR), or incentives, it was hoped that a win-win outcome could be achieved for both the shophouse owners and government.

(2) Property Rights Issues: Currently the shophouses are mostly owned by 2 to 3 generation households, or an entanglement of property rights due to separation, relocation, loss of contact, and rental issues etc. These issues often result in the encountering of many difficulties during renovation of shophouse interiors. Consequently, when the government
* Graduate Student, Dept. Graduate School of Design Doctoral Program, Yunlin University of Science and Technology, Taiwan

** Prof., Dept. of Architecture and Interior Design, Yunlin University of Science and Technology, Taiwan 国立雲林科技大学設計学＼cjkstart博士後期課程

国立雲林科技大学 教授.工博 
renovates this district, the shophouse owner's agreement must be obtained, or the property development rights must be transferred by exchanging the occupying land area of the shophouse for incentives. This strategy encourages the shophouse owners to spontaneously renovate the shophouses. However, because the shophouses are adjacent architectural structures, the renovation of a single shophouse will not be able to contribute comprehensive benefits, thus lowering the willingness for repair and renovation.

(3) Renovation Design Issues: As previously described, because of the limitations posed by property rights and the need to obtain owner agreement for renovations to be conducted, the effectiveness of renovation of the street district and shophouses have been limited. Furthermore, the government has not established relevant guidelines nor provided the public with renovation design and construction principles. Thus, even if people are willing to undertake renovations, the lack of traditional craftsmen, skills, and materials result in the loss of the original appearance and feel once the renovation is completed. Similarly, private ownership rights hinder street landscape improvements because improvement work is often limited to the paved street, street lighting, and signposts, while aesthetically unpleasant equipment cables and signboards are still hung freely on the facade of the shophouses. This adversely affects the appearance of shophouse facades and the urban landscape, preventing the historical features and characteristics of the local area from being appropriately displayed.

(4) Business Operations Issues: The traditional shophouse form of business operations has changed significantly in recent times. The business potential mostly lies within the surrounding newly emerged markets and street districts. The shophouse district has lost the prosperity it had in the past, and the loss of competitiveness has resulted in population outflow and street district hollowing, which impacts the willingness to repair, renovate, and investment in shophouses.

(5) User Requirement Issues: Due to time change, the size of families, and living requirements, most shophouses have all undergone some degree of renovation. To increase the comfort of living in shophouses, modern electrical equipment has been installed. However, the methods employed to install this equipment affects the building structure; thus, a practical discussion of this issue must be conducted.

Considering the existing shophouse district renovations in Taiwan, the renovation process for shophouses along the Minquan Street Districts, Sanxia Township, Taipei City, (the "Sanxia shophouse district") are some of the more well preserved and historically significant traditional shophouses remaining in Taiwan. The renovation process for the Sanxia shophouses was unlike any other. Successful completion was only realized after consent was received for the use of land within $15 \mathrm{~m}$ of both sides of the street through the government's first public sector levy. After resolving property rights controversies, operations regarding comprehensive street landscape renovations and interior spacing within $15 \mathrm{~m}$ ran rather smoothly. For this renovation project, the government proposed specific construction principles, which were incorporated into the guidelines. In 2000, Article 27 of the Urban Planning Law was used to initiate planning for the redevelopment work at that Sanxia urban street location, with the actual renovation starting in 2004 and being completed by the end of 2006 .

However, did the completion of the Sanxia shophouse district demonstrate successful planning and regulatory control? How were the improvements to street landscape and establishment of facilities within the plans perceived by local users? Were the renovation projects designed to invigorate the commercial value of traditional shophouse districts to meet modern commerce requirements? How has the increase in tourists because of the renovation affected the local residents? More specifically, did the renovation of the Sanxia shophouses raise the quality of life of the users? What effect did the introduction of modern electrical appliances and equipment have on the interior environment of the Sanxia shophouses? These are issues that we intend to discuss in this study.

Although currently, a certain amount of research on shophouse construction has been carried out, most studies have focused on the exploration of developmental variation, spatial composition, and facade style decoration of shophouses. The issue of evaluation of renovation and re-utilization of shophouses has not received an in-depth exploration thus far.

Therefore, based on the renovation issues and topics planned for discussion, four key aspects, namely, "legal issues," "renovation design issues," "business operations issues," and "user requirement issues" were set as the evaluation criteria. We also conducted an questionnaire survey of the street landscape beautification results by surveying shophouse users (both residents and businesses). We analyzed the users' satisfaction with the public street facilities and renovated shophouse interiors (Fig. 4). The results of this study can provide a reference for future preservation of other shophouse district through renovation and re-utilization. The objectives of this study were as below:

(1) Evaluate the investigative results of the renovation of the Sanxia shophouse district.

(2) Analyze the usage appraisal of the post-renovation Sanxia shophouse district.

\section{Research Methods and Construction of Questionnaires}

This study adopted non-participant observation and field investigation to collect basic data. Questionnaire survey was used to examine the views of users and to understand the degree 
of their ambivalence towards shophouse renovation. The study methods used are described below:

(1) Non-Participant Observation: Pairs of researchers conducted two observations for this study ${ }^{\text {ii }}$. The first observation was conducted in July 2007 with non-participants (visitors). First, based on the renovation area highlighted in the construction drawingiii, a data matching and observation exercise was conducted in the Sanxia shophouse district. This exercise demonstrated that the renovation project involved the improvement of the overall landscape in the district, including the appropriate restoration and setting of guidelines for "the first $\mathrm{Lo}^{\mathrm{iv}}$ " of shophouses. Thus, the scope of the research area was defined as the Sanxia street district and shophouses post-renovation. The second observation involved observing users within the area previously defined; the users' daily activities and interactions with the surrounding environment and facilities were recorded. Furthermore, this observation exercise also considered the current use situations, renovation results, design methods, and construction work quality; photographs were taken as records. Questions arising from this exercise were posed to local users to understand the users' behavior and attitudesv. Information of problems that occurred post-renovation and user behavior was then employed to develop a semi-structured questionnaire ${ }^{\text {vi }}$, which eventually formed the basis of the interview conducted later during the field investigation.

(2) Field Investigation: Similarly, the field investigation was iterated three times between February 2008 and March 2008 by a pair of researchers. The objectives of the first iteration was to investigate the current use of the overall street environment, the roads, lights, signboards, parking lots, public toilets, and street furniture. Necessary dimensions map and quantity measurements were obtained to evaluate the current use of the facilities in the street district. The research subjects of the second iteration were primarily the shophouses. One researcher interviewed shophouse users using the semi-structured questionnaire, enabling the users to express their feelings and opinions. Meanwhile, the other researcher photographed, spatially surveyed, and mappedvii "the first Lo" of the shophouses. Once the data obtained from the first two iterations were compiled into a basic dataset, gaps in the dataviii were identified and the field investigation was conducted for a third time to adjust and enhance the data.

This dataset was obtained from the 93 shophouses in the district, excluding new style constructions (buildings No. 40, 42, and 147), temples (building No. 48 to 56), people unwilling to participate in the research, and empty shophouse (building No. 92). The result of the field investigation is a dataset with information of 58 shophouses. However, samples showed that few of these shophouses are used as residential buildings (10.8\%, please refer to Table 4); "the first Lo" of the shophouses were primarily rented to businesses as stores. The rear of these shophouses connecting to the stores is suitable for residential purposes. For example, the rear of shophouse No. 76 (Fig. 1) included a large hall, toilet, kitchen (restaurant), worship hall, and rooms for living space. Therefore, in addition to the original residents, businesses who rent the space are also users of the shophouses. Because they have the most direct and thorough experience of using the shophouses, this study included the property rights holders, residents, shop owners, and staff employed at Sanxia shophouses as the target participants of the questionnaire. In other words, the target participants were shophouse users, who included the "residents" and the "businesses".

The purpose of the field investigation was to understand the current usage requirements and relevant situations of the shophouses exterior and interior spaces. The analysis result can be used as a basis for future questionnaire development, and can be compared with the results of statistical analysis to further clarify the key impact factors in the gap between user opinions and perceptions.

(3) Questionnaire Survey Procedure: Using the results obtained by combining the previous two data collection methods and information from relevant literature, we designed a structure for the questionnaire needed for our survey. After consulting with related experts, the questionnaire was further revised and a trial survey was conducted. After the trial, the questionnaire was again revised, this time based on the results of the examination and views of the subjects in the previous trial, which produced the final, formal version of the questionnaire. The questionnaire was drawn up based on the Likert scale. A Likert scale is an interval-based multiple-choice style of questioning commonly used in questionnaires. In this form of questionnaire respondents specify their level of agreement with a statement in terms of "strongly agree," "agree," "neither agree nor disagree," "disagree," or "strongly disagree." The respondents are then assigned a score of 5 points, 4 points, 3 points, 2 points, or 1 point to each of their ratings. A higher score indicates that

the 4th Lo thatio. the 3rd Lo batio! the 2nd Lo

Fig.1 Shophouse No. 76 
the respondent has a strong view or feeling towards a particular item in the questionnaire. Finally, statistical results were generated which served as the basis for user appraisal of post-renovation shophouse district.

In addition, the questionnaire was completed during face-to-face interviews in two times by a pair of researchers, which considered that a subject's personal feelings of his/her experiences would be strongest at the location designated for this study. Not only could a questionnaire-type interview immediately reflect the feelings of the subjects, it could also improve recovery rate of the questionnaires. The survey period for this study was mid-August to late-October of 2009. In addition, considering the homogeneous distribution of the questionnaires, the study carried out a comprehensive survey (excluding new style constructions, temple, and empty shophouse). In other words, using the convenience sampling approach, respondents were requested to complete the answers through door-to-door interviews of residents or businesses, which, once completed and collected, had a recovery rate of $100 \%$. Excluding a few unwilling residents and businesses, a total of 114 questionnaires were returned. Five of which were deemed invalid and excluded (incomplete responses), resulting in a total of 109 valid questionnaires. Data from these 109 valid questionnaires were analyzed using SPSS statistical software.

\section{The Renovation Scope and Guidelines and Research Focus}

The old name for Sanxia was Sanjiaoyong. Sanxia was where Quanzhou (Fujian Province) immigrants came in 1685 to develop what was then uncultivated land. During the Japanese colonial period, due to the narrow twists and turns of the street and its poor sanitation, the Japanese government implemented a "building and street improvement program" in 1916, which broadened Sanjiaoyong Street (today's Minquan Street) and set up the "five-foot way" (Ding-a-ka in Taiwanese), establishing the appearance of buildings along both sides of the street.

However, with the passing of time and the increasing danger of natural disasters, most of the shophouses were facing collapse, decay, and even destruction. Changes in usage requirements further emphasized the need for shophouses to be renovated if they were to be continuously used. Therefore, in the name of "preservation of cultural assets" and "protection of public interestix" under Article 27 of the Urban Planning Law of 2000 the Sanxia shophouse district was designated a "special historical site", which permitted their renovation through the use of targeted land acquisition.

The 2000 "Urban Design Standards" (Table 1) within the "Sanxia Urban Change Plans (Sanjiaoyong Old Street District Redevelopment Project)" includes 7 regulations and 14 guidelines. Of the regulations stipulated, Guidelines 1 to 4 , and Guideline 9 were designed to establish a preservation standard for the Sanxia Street district and shophouses. Guidelines 5 to 8 directly impacts the unification of locations and designs of signboards, influencing the planning of lighting, and also limiting the installation of equipment or cables on the facades of shophouses. Guidelines 10 and 11 promote the installation of underground cables, paved streets, and street chairs ${ }^{x}$. To understand how renovations implemented according to specific regulations and restrictions can improve and beautify the street environment, we included landscape beautification, as defined in the regulations (including cables, lighting, signboards, and street furniture), in our questionnaire for evaluation. Furthermore, because the Sanxia shophouse district aims to further develop its tourism market, to counteract the impact tourists have on the district, this study also conducted a user evaluation of necessary public facilities, such as public toilets, parking lots, and trashcans.

Table 1 Chart of relevant standard regulations for urban design ${ }^{\mathrm{xi}}$ 1. Conservation of shophouse facades Guideline 1: Preserve the facade style and decorations of shophouses and alleys Guideline 2: Avoid any interference with the facade.

\begin{tabular}{|c|}
\hline 2. Conservation of the "five-foot ways" and "the first Lo" \\
\hline $\begin{aligned} & \text { Guideline 3: } \text { Any renovation and restoration to original condition should } \\
& \text { preserve the styles from the "five-foot ways" to "the first Lo" with } \\
& \text { enhancements on the structure. }\end{aligned}$ \\
\hline Guideline 4: Maintain continuous "five-foot ways" with drainage treatment. \\
\hline 3. Advertising signboards and cables \\
\hline $\begin{array}{l}\text { Guideline 5: Place signboards on horizontal blocks without interfering with the } \\
\text { facade. }\end{array}$ \\
\hline Guideline 6: Facade and cables should be combined and designed as a whole. \\
\hline $\begin{array}{l}\text { Guideline 7: } \begin{array}{l}\text { Avoid using advertising light-boxes and apply direct lighting or } \\
\text { backlighting. }\end{array}\end{array}$ \\
\hline 4. Night lighting \\
\hline $\begin{array}{l}\text { Guideline 8: } \begin{array}{l}\text { Use street light lamps with distinctive features to shape the } \\
\text { nighttime atmosphere. }\end{array} \\
\end{array}$ \\
\hline 5. Streets (alleys) landscape improvement \\
\hline Guideline 9: Maintain the width and style of the existing streets (alleys). \\
\hline $\begin{array}{l}\text { Guideline 10: Pave the sidewalks to improve quality and add street furniture } \\
\text { and landscape plants. }\end{array}$ \\
\hline Guideline 11: The street district cables should be underground. \\
\hline 6. Guides to cultural landscape \\
\hline Guideline 12: Design for presenting historical features on tour routes. \\
\hline 7. Park lands \\
\hline Guideline 13: Apply green plants according to the local features. \\
\hline $\begin{array}{l}\text { Guideline 14: Build underground parking spaces and plan the line of mot } \\
\text { other attractions. }\end{array}$ \\
\hline
\end{tabular}
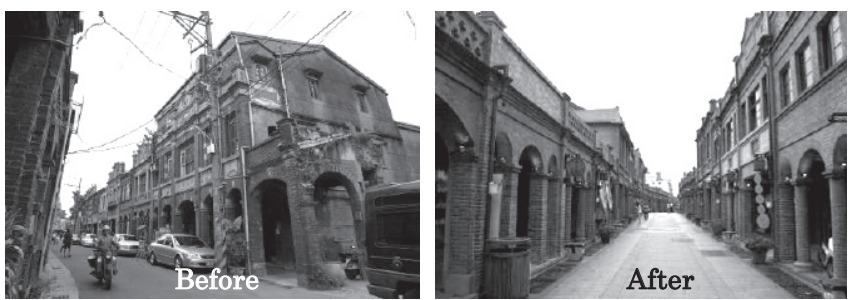

Fig. 2 Photographic comparison of Minquan Street before and after renovation ${ }^{x i}$

In addition, the "Sanxia Urban Change Plans" illustrate the stipulations for shophouse preservation, which stipulate the renovation of shophouses through the means of "preservation of features and stylexiii" and "restoration of original condition ${ }^{\text {xiv". }}$ The range of renovations started from facades on the side of the street and ended with "the first Lo". Major renovation and reconstruction was conducted on a total of 93 shophouses (83 to 


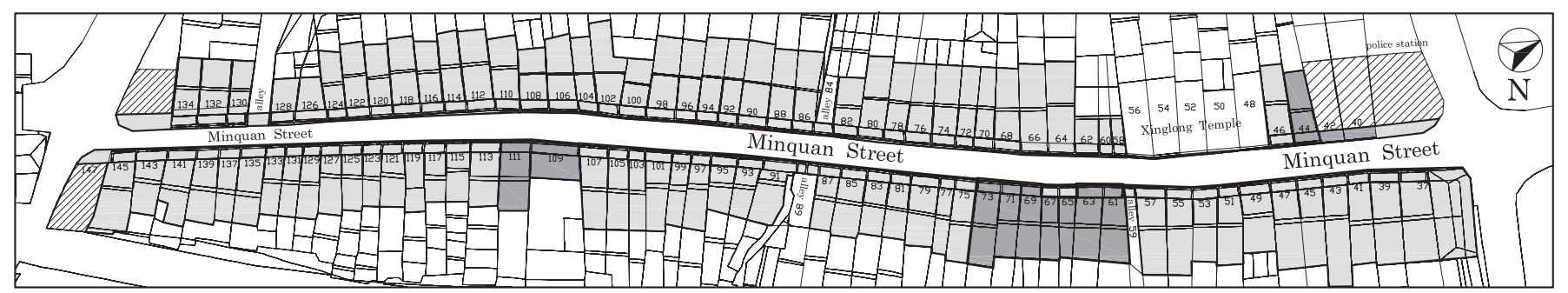

Fig.3 Preservation of features and style and restoration of original condition case location diagram ${ }^{\mathrm{xv}}$

$\square$ Preservation of features and style VIIIIA New builder $\square$ Restoration of original condition

preserve the features and style and 10 to restore their original condition), and 104 facades of shophouses and alleys (Fig.2 to 3).

However, no regulations have been established for the interior of the shophouses. Thus, besides the repair and recreation of the structure of shophouses, renovation of the interior spaces included retro recreations of interior materials, such as red-brick floors, white-grey walls, and timber staircases. The interior space can be decorated according to the user's demands after the basic renovations have been completed. Thus, to explore whether the interior renovations met the users' requirements, a post-use evaluation was conducted on various items, such as the interior area, natural ventilation, and air conditioning system after renovation.

Based on the above information, the evaluation and analysis of this research were divided into three main sections: (1) Evaluation of renovation and utilization of the landscape of the street district in terms of (a)underground cabling, (b)night lighting, and (c)signboards; (2) Evaluation of the renovation and utilization of infrastructure and equipment, such as (a)public toilets, (b)parking lots, (c)trashcans, and (d)street chairs; and (3) Evaluation of the renovation and utilization of the interiors of the (a)shophouses in terms of the area of the interiors, and (b) the ventilation and $\mathrm{AC}$ systems. The renovation method and post-utilization evaluation are illustrated in the following sections (Fig.4).

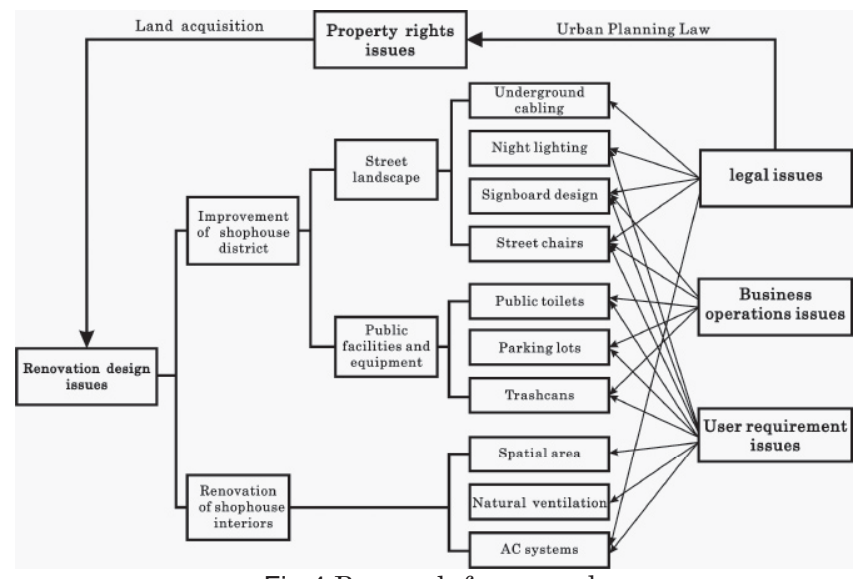

Fig.4 Research framework

\section{Post-Renovation influences on Business Operations}

According to the current status survey based on the 2000
"Sanxia Urban Change Plans," before renovation, residential use was the largest category of users of Sanxia shophouses at the time, accounting for $43.0 \%$ of the overall total (40/93 buildings). Commercial users accounted for a slightly smaller proportion, $40.9 \%$ (38/93 buildings); among them, cultural items stores accounted for $17.2 \%$ (16/93 buildings), which were considered a relatively major industry at the time. The dining industry (5/93 buildings) and funeral industry (5/93 buildings) were equally second, each was at $5.4 \%$. The numbers showed that, of the types of single-use businesses on Minquan Street at the time, the rate of residency and vacancy was about $60 \%$ of all cases (Table 2).

Table 2 Types of Sanxia shophouse uses before renovation ${ }^{\mathrm{xvi}}$

\begin{tabular}{|c|c|c|c|}
\hline Type & Building No. & Use Category & Building No \\
\hline Residential & $40(43.0)$ & Purely residential & $40(43.0)$ \\
\hline \multirow{9}{*}{$\begin{array}{c}\text { Commercial } \\
\text { premises }\end{array}$} & \multirow{9}{*}{$38(40.9)$} & General services & $2(2.2)$ \\
\hline & & Repair industry & $2(2.2)$ \\
\hline & & Dining industry & $5(5.4)$ \\
\hline & & Entertainment industry & $1(1.1)$ \\
\hline & & Funeral industry & $5(5.4)$ \\
\hline & & Hardware/grocery & $3(3.2)$ \\
\hline & & Cultural items store & $16(17.2)$ \\
\hline & & Pet industry & $1(1.1)$ \\
\hline & & $\begin{array}{l}\text { Others (Only marked as commercial, } \\
\text { did not specify the type of business) }\end{array}$ & $3(3.2)$ \\
\hline \multirow{2}{*}{ Other } & \multirow{2}{*}{$15(16.1)$} & Empty house & 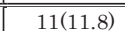 \\
\hline & & Purpose unknown & $4(4.3)$ \\
\hline Total & $93(100.0)$ & & $93(100.0)$ \\
\hline
\end{tabular}

Table 3 Businesses and activities allowed under Sanxia's regulatory limitations ${ }^{\mathrm{xvi}}$

\begin{tabular}{|c|c|c|c|}
\hline \multirow{8}{*}{$\begin{array}{c}\text { Allowable } \\
\text { uses }\end{array}$} & Residential & \multicolumn{2}{|c|}{ Pure residential } \\
\hline & \multirow{6}{*}{ Commercial } & Repair industry & Healthcare services industry \\
\hline & & Retail industry & Funeral industry \\
\hline & & Dining industry & Fitness industry \\
\hline & & General Services & \\
\hline & & \multicolumn{2}{|c|}{$\begin{array}{c}\text { Local character hotel or establishment of accommodation } \\
\text { facilities }\end{array}$} \\
\hline & & \multicolumn{2}{|c|}{ Other industries as recognized by Urban Design Review } \\
\hline & Religious & Temples anc & eligious buildings \\
\hline \multirow{3}{*}{$\begin{array}{l}\text { Allowable } \\
\text { facilities }\end{array}$} & \multicolumn{2}{|c|}{ Residential recreational facilities } & Cultural Performance Facilities \\
\hline & \multicolumn{2}{|c|}{ Community communication facilities } & Pre-school facilities \\
\hline & \multicolumn{2}{|c|}{ Agronomic and horticultural facilities } & Social Education Facilities \\
\hline \multirow{2}{*}{\begin{tabular}{l|} 
Allowable \\
activities
\end{tabular}} & \multicolumn{3}{|c|}{ Community groups } \\
\hline & \multicolumn{3}{|c|}{ Culture and Arts Associations } \\
\hline
\end{tabular}

As specified in the regulations, renovation was encouraged to begin with by engaging with local culturally and historically related industries, which allowed for management of operations to be more compatible with the characteristics of local industries and businesses. At the same time, businesses that could easily cause traffic disruption and environmental impact were kept away from the area; these included discount stores, 
supermarkets, general hospitals, bars, and mechanical maintenance ${ }^{\text {xviii }}$. Industries and activities that were permitted to operate under the rules and regulations are listed as follow (Table 3).

Post-renovation, a big difference was observed in the Sanxia shophouse district regarding the nature of the use and the activities they conducted. Overall, sightseeing and tourism promoted much of the economic activities for local businesses. This was especially true for local stores, which grew from the previous $40.9 \%$ (38/93 buildings) to $88.1 \%$ (82/93 buildings). In contrast, residential use was greatly reduced and vacant houses dropped from the previous units to the current one unitxix. Cultural items stores and the dining industry proliferated, which are primarily related to literature, history, and art related or snack-based businesses(Table 4). Stores such as tailors, chop engravers, fruit stands, funeral accessories, grocers, and hardware stores had already moved out. In addition, plumbers/electricians, entertainment industry, and pet industry could not operate due to lack of regulatory approval. Led by the development of tourism, many local residents and businesses believed that the renovation of the Sanxia shophouse district indeed raised the prosperity and development of local businesses, with the average score in the questionnaire reaching "agree"xx (M =4.06). Among the 73 store lessees, more than $70 \%(54 / 73$ persons) expressed a willingness to continue their leases in the future, which showed that renovation work really had been substantially effective for the local tourism industry.

Table 4 Types of Sanxia shophouse uses after renovation

\begin{tabular}{|c|c|l|r|}
\hline Type & Building No. & \multicolumn{1}{|c|}{ Use Category } & Building No. \\
\hline Residential & $10(10.8)$ & Purely residential & $10(10.8)$ \\
\hline \hline \multirow{4}{*}{$\begin{array}{c}\text { Commercial } \\
\text { premises }\end{array}$} & \multirow{3}{*}{$82(88.1)$} & General services & $0(0.0)$ \\
\cline { 3 - 4 } & & Repair industry & $1(1.1)$ \\
\cline { 3 - 4 } & & Dining industry & $30(32.3)$ \\
\cline { 3 - 4 } & & Entertainment industry & $0(0.0)$ \\
\cline { 3 - 4 } & & Funeral industry & $2(2.2)$ \\
\cline { 3 - 4 } & & Hardware and grocery & $0(0.0)$ \\
\cline { 3 - 4 } & & Cultural items stores & $0(43.0)$ \\
\cline { 3 - 4 } & & Pet industry & $7(7.5)$ \\
\cline { 3 - 4 } & & Fashion industry & $2(2.2)$ \\
\cline { 3 - 4 } & & Dining/Cultural Fusion & $1(1.1)$ \\
\hline \hline Other & $1(1.1)$ & Empty house & $93(100.0)$ \\
\hline Total & $93(100.0)$ & & \\
\hline
\end{tabular}

Note: Does not include Xinglong Temple (Nos. 48 56) Nos. 40, 42, 147.

General Services: Tailors, Chop stores.

Repair industry: Bicycle shops, Plumbers/Electricians.

Dining industry: Food stalls, Bakeries, Shaved ice stores, Tea drinks stores, Fruit stores.

Entertainment industry: Video game stores.

Funeral industry: Coffin shops, Funeral supplies.

Hardware and grocery industry: Hardware and grocery stores.

Cultural items stores: Wood sculpture shops, Arts, and craft stores, Toy stores, Antique shops, Fabric stores, Tea stores.

Fashion industry: Clothing stores, Shoe stores.

Dining/Cultural Fusion: A cultural items store that also sells foods.

\section{Evaluation of the Renovation and Utilization of the Street Landscape}

\section{5-1. Underground Cabling}

Prior to renovation, all cables of the Sanxia shophouse district were randomly hung on the facades by the users, which affected the appearance of the facades. Hence, according to the regulations governing the Sanxia shophouse district, all cables must be underground. Any cables that need to run over ground must be hidden in corners or grooves of buildings. Electrical distribution junction boxes must be uniformly placed on the rear gable wall in accordance with regulations covering the street landscape. This avoids any visual impact on the street facade due to unnecessary exposure of cable lines after street renovation. According to interviews with local users, in contrast, unnecessarily exposed cable lines and poles that cannot be well hided in some traditional areas where shophouses are privately owned may be considered visually messy. As a result, residents and businesses are satisfied with the underground cabling plan $(\mathrm{M}=4.16)$.

\section{5-2. Night Lighting}

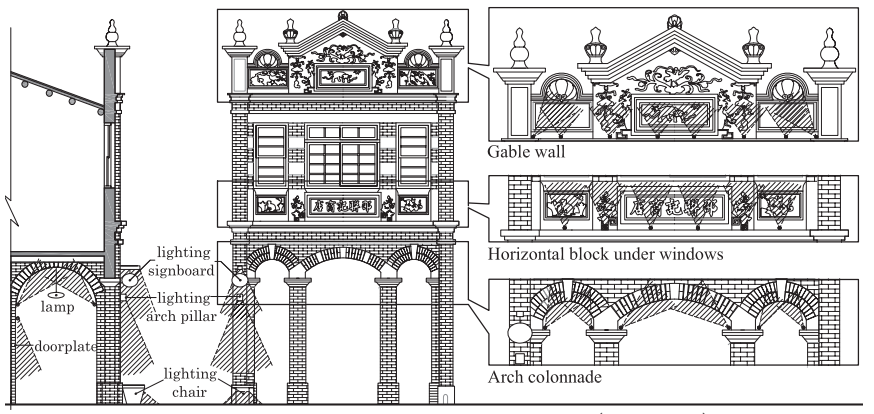

Fig.5 Night lighting of Shophouse (No. 107)

Although provisions in the regulations stipulate that street lights must meet the local requirements for landscape atmosphere, in order to shape the night atmosphere, the night lighting design of Minquan Street at the beginning of renovation did not adopt street style lighting. Instead, indirect lighting of building exteriors was adopted using projection lamps so that people could feel the beauty of the architecture of the shophouses, even at night. The use of street lights should avoid affecting the line of sight for appreciating the facades.

The range of lighting varies depending on the number of floors of a shophouse: a shophouse with two to three floors is divided top-down into gable wall, horizontal block under windows, and arch colonnade. In a single floor shophouse, since the building facade lacks a horizontal block, lighting only covers the gable wall and arch pillars (Fig. 5). In terms of lighting of the "five-foot way" corridor, in addition to lighting under the overhand eaves of the "five-foot way", the lighting was mainly for the continuous arch and the doorplate. Indirect lighting was designed into the details for street signboards, pillars, and chairs. Because the lighting was created for atmospheric reasons, the majority of residents and businesses were highly appreciative and agreeable $(\mathrm{M}=4.28)$.

\section{5-3. Signboard Design}

A majority of early shophouse signboards were positioned in the center of the horizontal block. Often the two sides of the 
signboard are decorated with an auspicious pattern (Fig. 6). The other method of placing the signboard is in the form of a placard hanging across the entrance to the interior of the shophous (Fig. 7). But in recent times, large light box signboards have become prevalent, occupying the main wall of shop facades (Fig. 8). The holes drilled through the wall for the metal framework that supports the signboard have caused some damage to shophouse facades. Therefore, standards for signboards are stipulated in the regulations. There are eight types of signboards with Sanxia's traditional features available for use (Figs. 9 to 16). Their styles are designed in accordance with the characteristics of local industries such as traditional indigo dyeing, tea, lanterns, snacks, and toys. Signboard dimensions must stay within $(45 \times 53)$ $\mathrm{cm}$. The graphic design within the inside margin of the signboard must be inside $(40 \times 40) \mathrm{cm}$. The height of the signboard must be uniformly above $3.1 \mathrm{~m}$ on the arch pillar of facades.

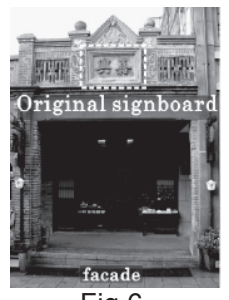

Fig.6

Original signboard

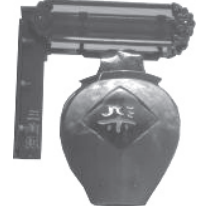

Fig.9

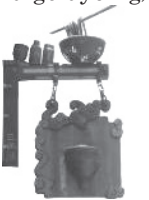

Fig.13

(Snack)
(Indigo dyeing)

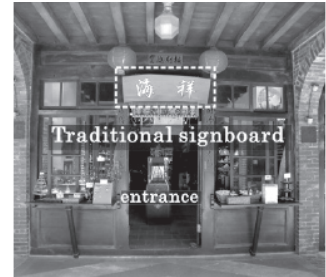

Fig. 7

Traditional signboard

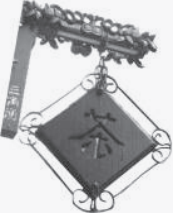

Fig.10

(Tea)

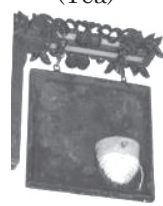

Fig. 14 (Whipping top)

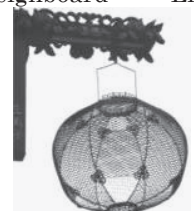

Fig.11 (Lantern)

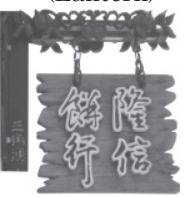

Fig. 15

(Square)

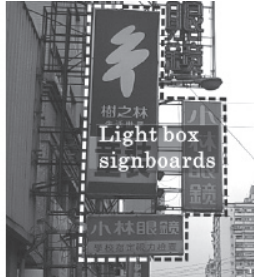

Fig.8

Light box signboards

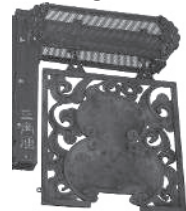

Fig.12 (Calabash)

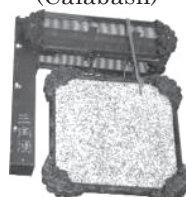

Fig. 16

(Square)
After renovation, signboards on the Sanxia shophouses appear uniform and neat. In terms of uniformity of signboards, opinions of local users were in agreement $(\mathrm{M}=3.78)$. However, in terms of graphic designs of signboards, most users responded, "neither agree nor disagree" $(\mathrm{M}=2.78)$. Residents and businesses also believed that the sizes of the signboards were too small to be easily seen $(\mathrm{M}=3.70)$. Most store owners thought that signboards must be able to display business type and store name. But currently graphic designs within the signboard are limited to $(40 \times 40) \mathrm{cm}$, which only allows business types to be shown and not store name. This is different from light box signboards presently on display between buildings, indicating a low level of acceptance of the current signboard design.

Furthermore, laws and regulations stipulate that local businesses shall not arbitrarily install signboards, and the original signboards positioned in the center of the horizontal block of shophouses must be preserved with its original store name and must not be modified. Additionally, no goods or articles may be placed in the corridor of the "five-foot way", including the signboards. Some of the businesses indicated that even though signboards had gone through a complete planning and design process, some of the designs are still based on business type, while other signboards are more arbitrary. When the nature or owners of businesses change, these signboards are often unable to meet the requirements of the new business or owner; thus, the signboards may be modified or even covered by businesses. As a result, only $24 \%$ (26/109 persons) users said they liked the new signboard design, and $37 \%$ (40/109 persons) users expressed their dislike of the new signboard design requirements.

\section{Evaluation of Public Facilities and Equipment Usage 6-1. Public Facilities}

Regarding the use of public facilities, overall results have been negative. Indications are that users feel very dissatisfied with respect to public toilets $(\mathrm{M}=1.74)$, parking lots $(\mathrm{M}=1.84)$, and trashcans $(\mathrm{M}=2.08)$.

The existing public toilets are mainly located in Xinglong Temple, where the men's room has three urinals and two lavatories. The women's room has five lavatories. There is also a common sink for hand washing. However, this is wholly inadequate, especially during weekends and festivals. Tourists are forced to use the public toilets in the Sanxia Zushi Temple on Changfu Street, the History Museum on Zhongshan Road, and the Presbyterian Church on Minzu Street (Fig. 17). There are even occasions when tourists have to use the toilets in local stores, causing distress to local residents and businesses. This has all led to a negative result. Although the planning of public toilets and other facilities was an integral part of public construction, the lack of planning for public toilets in the current situation has resulted in " $\mathrm{t}$-test" results $(\mathrm{t}=-4.245, \mathrm{p}=0.00<0.05)$ that show strong negative evaluation from those who had participated in the renovation works $(M=1.20)$ and those who had not $(\mathrm{M}=1.86)^{\mathrm{xxi}}$. Shophouse users felt that public toilets should have been planned in advance. Shophouses are private spaces where fixed toilets cannot be installed for public use, although portable toilets can.

In terms of the number of parking lots, on last count there were three close to the Sanxia shophouse district (two are located on Zhongshan Road and one is located on Guangming Road). There are no parking lots located in Sanxia shophouse district itself (Fig. 17). Furthermore, local regulations stipulate that no parking is allowed anywhere on the streets and "five-foot ways" of the Sanxia shophouse district, causing some users to have to park their cars in nearby alleys or backyards. This is a major 
inconvenience for both local users and tourists. Even the taking of public transportation would still demand a 5 to $10 \mathrm{~m}$ walking distance (Fig. 17). All these led to a negative evaluation of the parking lots situation.

In addition, the Sanxia shophouse district currently has only two public trashcans available during weekdays, increasing to five during the weekend. A single trashcan measures $70 \mathrm{~cm}$ at its maximum diameter, with a height of about $107 \mathrm{~cm}$. But for an area that has become a special tourist destination, the number of trashcans in the Sanxia shophouse district is insufficient to meet the demands for organized events and festivals. The lack of trashcans has forced visitors to turn to local residents or businesses to take care of their trash, burdening and disturbing those businesses in the process. For this reason, businesses expressed dissatisfaction. But there was a range of differences between various users ( $\mathrm{t}$-test results: $\mathrm{t}=2.235, \mathrm{p}=0.028<0.05$ ). Pure commercial users $(\mathrm{M}=1.96)$ had greater dissatisfaction than combined residential and commercial users $(\mathrm{M}=2.50)^{x x i i}$.

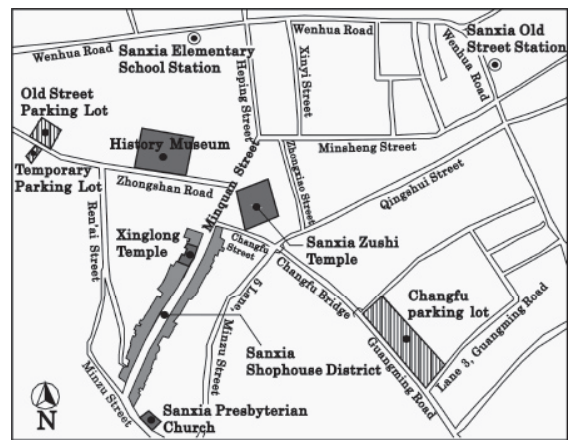

Fig.17 Public toilets, parking, and bus stops near the Sanxia shophouse district

\section{6-2. Street Chairs}

The chairs are made of hemlock spruce and marble, and are located on the sides of Minquan Street. During the daytime, people can enjoy their rest on the chairs. At night, the chairs can serve as nighttime lighting equipments (Fig. 18).

The evaluation of chair comfort reveals the level of "neither agree nor disagree" ( $\mathrm{M}=3.39)$. Approximately $26 \%(19 / 109$ persons) of the residents and businesses believe the chairs are inadequately comfortable. The "t-test" suggests $(\mathrm{t}=-2.546$, $\mathrm{p}=0.012<0.05)$ that users who participated in the renovation have lower results $(\mathrm{M}=2.45)$ than those who did not $(\mathrm{M}=3.03) \times x$ xiii

According the interviews, the lack of shade or trees over the chairs has rendered the residents and businesses unwilling to use the chairs, and forced them to escape from the radiant heat during the summer time by staying in the "five-foot ways". Hence, many local businesses would place wooden benches in their "five-foot ways" for themselves and for tourists to rest on. In addition, hemlock spruce is less water-proof, causing it to rot in the face of humidity. Some are even damaged due to external forces. At present, some of the chairs have already been damaged, which may cause negative feelings in respondents.

\section{Evaluation of the Renovation and Utilization of Shophouse Interiors}

\section{7-1. Spatial Area}

The current scope of renovation was concentrated within $15 \mathrm{~m}$ in "the first Lo" of shophouses. The 58 cases of shophouses collected for this study showed the different widths of the various "the first Lo" were mainly between 2.1 and $4.8 \mathrm{~m}$, with more than $70 \%$ of the cases between 3.6 and $4.5 \mathrm{~m}$. The depths of the various "the first Lo" were also wildly divergent; from $4.5 \mathrm{~m}$ to above $12.0 \mathrm{~m}$, but with approximately $46.6 \%$ (27/58 buildings) concentrated in 7.2 to $9.6 \mathrm{~m}$ (Table 5). Overall, although the differences among various areas of the interior space of "the first Lo" was significant, the evaluation of user demands for the usage area, regardless of whether it was for home business or for lease, showed that the current interior area was quite adequate $(\mathrm{M}=$ 3.59). In general, although shophouse space came in a variety of dimensions, shop operators could make adjustments under existing conditions. If the usage area was less than sufficient, then it was extended further towards the back. However, if there

Table 5 Dimensions of the first Lo of Sanxia shophouses- checklist

\begin{tabular}{|c|c|c|c|c|c|c|c|c|c|c|c|c|c|c|c|c|c|c|c|c|c|c|c|c|c|c|c|c|}
\hline Wepth & $\begin{array}{l}\text { Less } \\
\text { than } \\
4.5 \mathrm{~m} \\
\end{array}$ & $4.5 \mathrm{~m}$ & $4.8 \mathrm{~m}$ & $5.1 \mathrm{~m}$ & $5.4 \mathrm{~m}$ & $5.7 \mathrm{~m}$ & $6.0 \mathrm{~m}$ & $6.3 \mathrm{~m}$ & $6.6 \mathrm{~m}$ & $6.9 \mathrm{~m}$ & $7.2 \mathrm{~m}$ & $7.5 \mathrm{~m}$ & $7.8 \mathrm{~m}$ & $8.1 \mathrm{~m}$ & $8.4 \mathrm{~m}$ & $8.7 \mathrm{~m}$ & $9.0 \mathrm{~m}$ & $9.3 \mathrm{~m}$ & $9.6 \mathrm{~m}$ & $9.9 \mathrm{~m}$ & $10.2 \mathrm{~m}$ & $10.5 \mathrm{~m}$ & $10.8 \mathrm{~m}$ & $11.1 \mathrm{~m}$ & $11.4 \mathrm{~m}$ & $11.7 \mathrm{~m}$ & \begin{tabular}{|l|}
$12.0 \mathrm{~m}$ \\
and up
\end{tabular} & Total \\
\hline $2.1 \mathrm{~m}$ & $\cdot$ & $-\cdot$ & $\cdot-$ & $\cdot \cdot$ & -. & $\cdot \cdot$ & -. & $\cdot \cdot$ & -. & -- & $\cdot-$ & $\begin{array}{c}1 \\
(1.7) \\
\end{array}$ & $-\cdot$ & $\cdot$ & .. & $\cdot \cdot$ & $\cdot \cdot$ & $\cdot$ & .. & $\cdot$ & $\cdot-$ & $\cdot$ & $\cdot-$ & $\cdot-$ & $\cdot-$ & $\cdot-$ & -. & $\begin{array}{c}1 \\
(1.7) \\
\end{array}$ \\
\hline $2.4 \mathrm{~m}$ & -. &.- & .. & .. & -. & .. & -. & -. & .. & -. & .. & .. & -. & -- & $\begin{array}{c}1 \\
(1.7) \\
\end{array}$ & -. & .. & .. & $\begin{array}{c}1 \\
(1.7) \\
\end{array}$ & .. & .. & .. & -. & -. & .. & .. & -. & $\begin{array}{c}2 \\
(3.4)\end{array}$ \\
\hline $2.7 \mathrm{~m}$ & .. &.- & -. & .. & -. & -. & $\begin{array}{c}1 \\
(1.7)\end{array}$ & .. & .. & -. & .. & .. & .. & $\begin{array}{c}1 \\
(1.7)\end{array}$ & .. &.- & .. & -. & .. & .. & -. & .. & -. & -. & -. & .. & .. & $\begin{array}{c}2 \\
(3.4)\end{array}$ \\
\hline $3.0 \mathrm{~m}$ & -. &.- & .. & .. & -. & $\begin{array}{c}1 \\
(1.7) \\
\end{array}$ & -. & .. & .. & $\cdots$ & -. & -. & $-\cdot$ & .. & .. & $-\cdot$ & $\cdot-$ & $\begin{array}{c}1 \\
(1.7) \\
\end{array}$ & $\cdot-$ & -. & $\cdot-$ & .. & -- & $-\cdot$ & $\cdot-$ & $\cdot$ & .. & $\begin{array}{c}2 \\
(3.4)\end{array}$ \\
\hline $3.3 \mathrm{~m}$ & .. & \begin{tabular}{|c|}
1 \\
$(1.7)$ \\
\end{tabular} & -. & .. & -. & .. & .- & $\begin{array}{c}1 \\
(1.7) \\
\end{array}$ & .. & .. & .. & .. &.- & .. & -. & .. & .. & .. & .. & .. & .. & $\begin{array}{c}1 \\
(1.7) \\
\end{array}$ & .. & .. & .. & .- & $\begin{array}{c}1 \\
(1.7) \\
\end{array}$ & $\begin{array}{c}4 \\
(6.9) \\
\end{array}$ \\
\hline $3.6 \mathrm{~m}$ & $\begin{array}{c}1 \\
(1.7)\end{array}$ & -. & -. & .. & $\ldots$ & .. & -. & .. & -. & -. & $\begin{array}{c}1 \\
(1.7) \\
\end{array}$ & $\begin{array}{c}1 \\
(1.7) \\
\end{array}$ & .. & .. & .. & .. & \begin{tabular}{c|}
2 \\
$(3.4)$ \\
\end{tabular} & -. & .. & .. & .- & .. & -. & -. & .. & \begin{tabular}{c|}
1 \\
$(1.7)$ \\
\end{tabular} & -. & $\begin{array}{c}7 \\
(12.1) \\
\end{array}$ \\
\hline $3.9 \mathrm{~m}$ & .. &.- & -. & .. & $\begin{array}{c}2 \\
(3.4) \\
\end{array}$ & .. & $\begin{array}{c}1 \\
(1.7) \\
\end{array}$ & $\begin{array}{c}1 \\
(1.7) \\
\end{array}$ & $\begin{array}{c}1 \\
(1.7) \\
\end{array}$ & .. & .. & $\begin{array}{c}2 \\
(3.4) \\
\end{array}$ & .. & $\begin{array}{c}1 \\
(1.7) \\
\end{array}$ & $\begin{array}{c}1 \\
(1.7) \\
\end{array}$ & .. & $\begin{array}{c}1 \\
(1.7) \\
\end{array}$ & & $\begin{array}{c}2 \\
(3.4) \\
\end{array}$ & $\begin{array}{c}1 \\
(1.7) \\
\end{array}$ & .. & .. & .. & .. & .. & .. & $\begin{array}{c}2 \\
(3.4) \\
\end{array}$ & $\begin{array}{c}14 \\
(24.2) \\
\end{array}$ \\
\hline $4.2 \mathrm{~m}$ & -. & \begin{tabular}{|c|}
1 \\
$(1.7)$ \\
\end{tabular} & -. & .. & $\begin{array}{c}1 \\
(1.7) \\
\end{array}$ & -. & .. & \begin{tabular}{c|}
2 \\
$(3.4)$ \\
\end{tabular} & -. & $\begin{array}{c}1 \\
(1.7) \\
\end{array}$ & $\begin{array}{c}2 \\
(3.4) \\
\end{array}$ & $\begin{array}{c}2 \\
(3.4) \\
\end{array}$ & $\cdot-$ & .. & & .. & $\begin{array}{c}1 \\
(1.7) \\
\end{array}$ & $\begin{array}{c}1 \\
(1.7) \\
\end{array}$ & $\begin{array}{c}1 \\
(1.7) \\
\end{array}$ & .. & -. & -. & .. & .. & $\begin{array}{c}1 \\
(1.7) \\
\end{array}$ & .. & $\begin{array}{c}1 \\
(1.7) \\
\end{array}$ & $\begin{array}{c}14 \\
(24.2) \\
\end{array}$ \\
\hline $4.5 \mathrm{~m}$ & -. & \begin{tabular}{|c|}
1 \\
$(1.7)$ \\
\end{tabular} & .. & .. & .. & -. & -. & .. & .. & .. & .. & -. & -. & .. & .. & $-\cdot$ & \begin{tabular}{c|}
1 \\
$(1.7)$ \\
\end{tabular} & & 2 & $\begin{array}{c}1 \\
(1.7) \\
\end{array}$ & .. & \begin{tabular}{|c|}
2 \\
$(3.4)$ \\
\end{tabular} & .. & .. & & & .. & $\begin{array}{c}7 \\
(12.1) \\
\end{array}$ \\
\hline $4.8 \mathrm{~m}$ & -. & \begin{tabular}{|c|}
1 \\
$(1.7)$
\end{tabular} & .- & \begin{tabular}{c|}
1 \\
$(1.7)$
\end{tabular} & .. & \begin{tabular}{c|}
1 \\
$(1.7)$
\end{tabular} & .- & .. & \begin{tabular}{c|}
1 \\
$(1.7)$
\end{tabular} & .. & $\begin{array}{c}1 \\
(1.7)\end{array}$ & .. & -. & .. & .. & -. & .. & .. & .. & .- & .. & .. & -. & -. & .. & .. & .- & $\begin{array}{c}5 \\
(8.6)\end{array}$ \\
\hline Total & $\begin{array}{c}1 \\
(1.7) \\
\end{array}$ & \begin{tabular}{|c|}
4 \\
$(6.9)$ \\
\end{tabular} & $\begin{array}{c}0 \\
(0.0) \\
\end{array}$ & $\begin{array}{c}1 \\
(1.7) \\
\end{array}$ & $\begin{array}{c}3 \\
(5.2) \\
\end{array}$ & $\begin{array}{c}2 \\
(3.4) \\
\end{array}$ & $\begin{array}{c}2 \\
(3.4) \\
\end{array}$ & $\begin{array}{c}4 \\
(6.9) \\
\end{array}$ & \begin{tabular}{c|}
2 \\
$(1.7)$
\end{tabular} & $\begin{array}{c}1 \\
(1.7) \\
\end{array}$ & $\begin{array}{c}4 \\
(6.9) \\
\end{array}$ & $\begin{array}{c}6 \\
(10.3) \\
\end{array}$ & $\begin{array}{c}0 \\
(0.0) \\
\end{array}$ & $\begin{array}{c}2 \\
(3.4) \\
\end{array}$ & \begin{tabular}{c|}
2 \\
$(3.4)$ \\
\end{tabular} & $\begin{array}{c}0 \\
(0.0) \\
\end{array}$ & \begin{tabular}{c|}
5 \\
$(8.6)$ \\
\end{tabular} & $\begin{array}{c}2 \\
(3.4) \\
\end{array}$ & \begin{tabular}{c|}
6 \\
$(10.3)$ \\
\end{tabular} & $\begin{array}{c}2 \\
(3.4) \\
\end{array}$ & \begin{tabular}{|c|}
0 \\
$(0.0)$
\end{tabular} & \begin{tabular}{|c|}
3 \\
$(5.2)$ \\
\end{tabular} & \begin{tabular}{|c|}
0 \\
$(0.0)$ \\
\end{tabular} & $\begin{array}{c}0 \\
(0.0) \\
\end{array}$ & $\begin{array}{c}1 \\
(1.7) \\
\end{array}$ & $\begin{array}{c}1 \\
(1.7) \\
\end{array}$ & $\begin{array}{c}4 \\
(6.9) \\
\end{array}$ & $\begin{array}{c}58 \\
(100.0) \\
\end{array}$ \\
\hline
\end{tabular}

(Note: Width $3.03 \mathrm{~m}$, depth $3.03 \mathrm{~m}$ increment. Width between $2.1 \sim 2.4 \mathrm{~m}$ exclusive is calculated at $2.1 \mathrm{~m}$ level, Depth between $4.5 \sim 5.1 \mathrm{~m}$ exclusive is calculated at $4.5 \mathrm{~m}$ level, and so on.) 
was plenty of usage area, then a number of stores could manage it together. Thus, the survey gave the situation "agree" status.

In contrast, because the business categories are legally limited, the business types are transformed from the sale of traditional processed agricultural products (for example: rice, teas, indigo dyeing) and daily necessities to the retail of cultural industries and dining industries. The need for space has decreased due to business transfers; thus, the users believe that the interior spaces of the shophouses are sufficient for business.

\subsection{Natural Ventilation and AC Systems}

The dimensions of traditional shophouses are narrow and long. For security reasons, the front and rear facades have very small and narrow openings. In order to improve interior ventilation and lighting, a patio is used as the primary medium for natural ventilation and lighting between buildings. However, with advances in modern equipment, whether patio can still meet the demands of modern day living is an issue this study investigated.

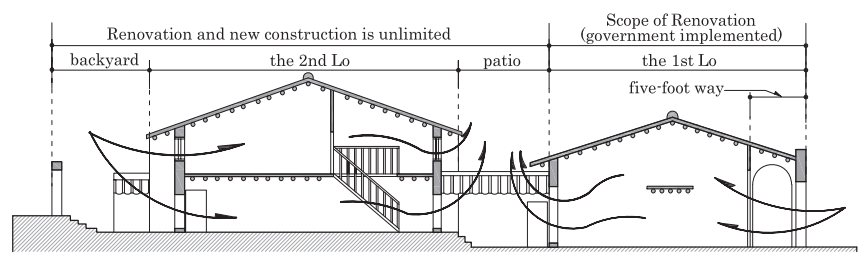

Fig.19 Natural ventilation diagram (No.114)xxiv

Statistical results indicated that most users still felt cool even without air conditioning $(\mathrm{M}=3.93)$, which showed that the interior climate can be partially adjusted through the patio. However, we learned from interviews that local businesses, in trying to increase purchasing levels of tourists and raise the comfort levels of dining environments, believed that air conditioning was still necessary equipment $(\mathrm{M}=3.53)$. This was especially true for stores that served food. Analysis of the two methods showed a "significant correlation" (position correlation: $\mathrm{p}<0.01, \mathrm{r}=0.404)$. This indicated that even though patio can be used to adjust the microclimate, most stores still preferred to add air conditioning systems to raise comfort levels in their commercial space environment. Furthermore, some businesses used full-length aluminum doors and insulation to further improve cooling efficiency. To preserve the original condition of the shophouses, laws have been passed to discourage the use of any modern-day equipment that could cause damage. Therefore, split type air conditioners were the predominant type of air conditioning system used, with the exterior units installed on the backside of the shophouses, in the patio, roof, or attic. The depth of "the first Lo" of a shophouse can vary from 4.5 to $12 \mathrm{~m}$ in length, requiring longer cables to connect the exterior part of the air conditioning unit to the outdoor part. Thus, up to $30 \%$ (31/109 persons) of users believed they would have some difficulties during installation of air conditioning units.

\section{Conclusion}

Renovation of the Sanxia shophouse district differed from that of other traditional street districts in Taiwan. The government's use of land acquisition in this case meant that, unlike buildings with private ownership rights, renovation of the Sanxia shophouse district was not restricted by limitations, such as only focusing on the facades or single shophouse. Instead, this project completely renovated the district's overall landscape and "the interior first Lo" of shophouses. Therefore, to investigate the users' (residents and businesses) feelings and evaluate the renovation project, we conducted a field observation by measuring, mapping, interviewing, obtaining photographic records, distributing questionnaires, and analyzing data to determine what aspects of the landscape, public facilities, and shophouse interior area of the district require further improvement. Our findings lead to the following conclusions:

\section{8-1. Evaluation of the Renovation of Street Landscapes}

Although the design and renovation to improve the Sanxia shophouse district was conducted according to regulations, local users provided positive feedback regarding the standardized methods for installing underground cables, night lights for atmosphere, and uniform signboards. The only negative feedback residents and businesses provided was that they were not afforded adequate flexibility to change the signboard graphics, and that the signboard dimensions were not sufficiently attention grabbing.

\section{8-2. Evaluation of the Renovation of Public Facilities and Equipment}

After the renovation project the number of stores in the Sanxia shophouse district increased by nearly $90 \%$. The shophouses users believed that this trend benefits the development of local commerce, and businesses who rented the spaces also expressed willingness to continue renting. However, as the local commerce continued to grow and tourists continued to visit the district, some shophouses users began having negative experiences. These users felt that the number of trashcans, public toilets, and parking lots were insufficient to meet the demands. Furthermore, the street chairs in the street district received an average rating for comfort. Additionally, because of a lack of supplementary measures, such as shades, and that some chairs were already damaged, caused a number of users to express dissatisfaction.

\section{8-3. Evaluation of the Renovation of Shophouse Interiors}

After the renovation project, because of the transformation to business operation types, businesses in Sanxia perceived that the interior spaces of the shophouses were inadequate. Additionally, the users felt that the regulations related to the patio in the interior of shophouses significantly improved the natural ventilation and air circulation. However, to increase the level of comfort in the commercial space, additional air conditioning systems were required. Nevertheless, a number of 
users believed that air conditioning cables were fairly difficult to install because of the depth of the interior space.

\section{References}

1) Taipei City Government, Sanxia Urban Change Plans (Sanjiaoyong Old Street District Redevelopment Project), Taipei, Taipei City Government, 2000.

2) Yu-jian $\mathrm{Xu}$ Architecture Firm, Feature Preservation, Original Condition Restoration and Street Landscape Improvement of Sanxia Sanjiaoyong Old Street - as construction drawing (Street landscape), Xu Yujian Architecture Firm, 2002.

3) Lo-Choi Huang, A Study on the Traditional Continuous Shophouses in Taiwan, Taichung, Tunghai University, 1983.

\section{Notes}

i. During the Japanese colonial period, a "Five-Foot Way," (Ding-a-ka in Taiwanese), referred to the frontage of the first floor of a building that shrinks backward where the upper portion can serve as shade from the sun or shelter from the rain, and the bottom corridor becomes an open access space for pedestrians.

ii. Participating field researchers were given training and orientation by the paper's author before they began the non-participant observation, field investigation, and questionnaire distribution. This was to prevent bias in the research results.

iii. Reference 2 .

iv. "Lo" is a unit measurement for building space in Taiwan. It points to the space gap under one roof or multiple roofs. The space between two "Los" is divided by a patio, which is used for ventilation and lighting as well as drainage (detailed in Fig. 19).

v. Before the users of this study were confirmed, the sample of local residents was chosen by random sampling, and consisted mainly of local shophouse residents and businesses. The scope of the interview include questions on the situations and condition of the street district pre-renovation and situations of business operations; design of renovation and construction process; situations of commercial development post-renovation, difference in street landscape, facilities, and shophouse utilization pre- and post-renovation; and above questions related to aesthetics, comfort, convenience, and utilization.

vi. The questionnaire consists of two main parts. One part contains questions on the basic background information about the users, including gender, type of property rights, shophouse usage type, and whether the user participated in the Sanxia renovation project. This part of the questionnaire is structured. The other part contains open-ended style questions of four key aspects including legal issues, business operations issues, renovation design issues, and user requirement issues. The questions were proposed to the users to ask about the results of the various renovations on the overall street district and the shophouses, the current situations of usage, the requirements, and user behavior.

vii. The interior space of "the first Lo" (including the width, depth (length), height, arrangement, and pillar positions) were measured accompanied with recording of the commodities and display cabinets arrangement inside the shophouses.

viii. Once the basic data obtained were sorted and compiled, it was found that no field investigation had been conducted on the district's public toilets, parking lots, and public transportation locations. The preliminary data also lacked dimensions measurements on signboards and street chairs. In addition, in the second field investigation, measurements on some shophouses were also missing. Therefore, it was necessary to conduct a third round of field investigation to supplement the data gap. During the latest round of investigation, businesses that had previously expressed unwillingness to participate in the research or shops that were previously not open were again visited and interviewed in an attempt to obtain information on more research samples. ix. Reference 1, pp. 1 .

x. In the "Urban Design Standards," Guideline 12 is regarding guides and specifies about the design of explanation boards and indication signs. However, the number of such explanation boards and indication signs are relatively small in quantity, and they have limited impact on the aesthetic pleasantness of the landscape, thus no further elaboration on this aspect is conducted. In addition, regarding regulations about park lands (Guidelines 13 and 14), because district studied in this research has no planned park land, it is not included in the discussion in this paper either.

xi. Organized by this research. (Reference 1, pp. 21-22).

xii. Pre-renovation photo provided by Urban and Rural Development Bureau, Taipei City Government.

xiii. The appearance of the shophouses should be preserved in its original condition, the interior allowing the incorporation of modern appliances and strengthened structure. The preservation ranges from the street side facades to "the first Lo" of the shophouses (Fig. 19).

xiv. A shophouse should be restored based on its original features when the shophouse that was demolished, tilted, or classified as a dangerous building cannot be preserved in its original condition.

xv. Reference 2, as re-described and annotated by this study.

xvi. Reference 1, pp. 5-6, as gathered by this study.

xvii. Reference 1, pp. 10-15, as gathered by this study.

xviii. See "Land Use Zoning Control" (Reference 1, pp. 15).

xix. From what we understand, the empty shophouse at No. 92 will still be rented out as a store in the future.

xx. Using scoring results by Likert scale, the size of the average number (hereinafter referred to as M) can reflect the level of the strength of the user experience and views. An average of above 4.50 points represents "strongly agree"; $4.49 \sim 3.50$ represents "agree"; $3.49 \sim 2.50$ represents "neither agree nor disagree"; 2.49 to 1.50 represents "disagree"; 1.49 points or less represents "strongly disagree."

xxi. Regarding the case of shophouse users, holders of property rights were mostly represented by tenants; accounting for $73.4 \%$ (80/109 persons). The holders of property rights (owners) were relatively small in number. In addition, current Sanxia shophouse usage types are divided as follows: pure commercial use and combined residential and commercial use, of which pure commercial use accounted for $78.0 \%$ (85/109 persons) and was the most common. In addition, during the renovation process, in order to increase public awareness of local culture and identity, local shophouse users were widely invited to participate. Of those surveyed, among all the subjects, only $18.3 \%$ (20/109 persons) had been involved in the Sanxia renovation project. This was designed to understand the difference between their thoughts during design and planning and their feelings after the completion of the project.

xxii. Refer to Note xxi.

xxiii. Refer to Note xxi.

xxiv. Reference 3, as re-described and annotated by this study.

\section{和文要約}

本研究は主に台北県三峡鎮民権街町屋区の再整備の使用状況と評 価について検討するものである。そのため、同区域の住民と商店を 対象として、実地調查とアンケート調査を行った。アンケート調查 の結果、使用者は再整備の店舗の面積が小さいながらも商売の要求 に十分達しており、商売の繁盛に役立つことになっていると思って いる。また、室内の風通し、周りの環境整備、パイプラインの地下 化、夜間照明、統一的な看板の設置などに対する好評も多い。一方、 ごみ箱、公衆トイレ、駐車場などの公共施設及び看板のサイズなど は実際の要求をまだ満足していないことが分った。 